\title{
Design-expert Software sebagai Alat Optimasi Formulasi Sediaan Farmasi
}

\author{
lyan Rifky Hidayat ${ }^{*}, 1$, Ade Zuhrotun², lyan Sopyan³ \\ ${ }^{1}$ Program Studi Sarjana, Fakultas Farmasi, Universitas Padjadjaran \\ 2Departemen Biologi Farmasi, Fakultas Farmasi, Universitas Padjadjaran \\ ${ }^{3}$ Departemen Formulasi dan Teknologi Farmasi, Fakultas Farmasi, Universitas Padjadjaran \\ Jatinangor, 45363 \\ *E-mail: iyan16001@mail.unpad.ac.id \\ (Submit 10/6/2020, Revisi 12/6/2020, Diterima 16/10/2020, Terbit 29/10/2020)
}

\begin{abstract}
Abstrak
Salah satu tahap dalam pengembangan obat adalah formulasi untuk mendapatkan formula yang optimum. Dengan formula yang optimum maka kualitas sediaan baik dan memenuhi parameter-parameter baku. Tahap ini dilakukan melalui eksperimen laboratorium dan analisis hasil percobaan yang umunya cukup memakan waktu. Untuk mengatasi hal tersebut dapat dilakukan pendekatan menggunakan piranti lunak dengan teknologi komputer yaitu Design-Expert software dalam membantu mendesain variasi formula pada preformulasi dan analisis hasil percobaan post formulasi. Tujuan dari review ini adalah muntuk mengetahui pemanfaatan Design-Expert software dalam penelitian formulasi dan optimasi. Metode penulisan kajian pustaka dilakukan dengan pencarian pada Google scholar dan ScinceDirect dengan kata kunci "Formulation" dan "Design-Expert" menghasilkan penemuan 63 artikel dan skrining dengan menerapkan kriteria inklusi yaitu artikel penelitian optimasi formulasi dengan rentang tahun terbit antara 2011 - April 2020 dan eksklusi berupa artikel berbentuk review artikel. Berdasarkan hasil kajian pustaka dapat disimpulkan bahwa Design-Expert software banyak digunakan dan bermanfaat dalam mengurangi waktu, dan biaya pengembangan formulasi.
\end{abstract}

Kata kunci: Formulasi, optimasi, software, design expert.

\section{Pendahuluan}

Formulasi dalam keilmuan farmasi artinya suatu kegiatan pembuatan sediaan yang berfokus pada perancangan komposisi bahan aktif maupun bahan tambahan dan telah melewati studi praformulasi. Dalam proses pengembangan obat baru, pada tahap formulasi secara konvensional yang dilakukan adalah menggunakan teknik mengubah satu variabel atau faktor pada satu waktu. Hal pertama yang dilakukan adalah studi mengenai pengaruh komposisi dan variabel proses pada bentuk sediaan, lalu mengubah satu faktor tunggal sekaligus menjaga konstanta. Namun, metode konvensional ini memiliki kekurangan yaitu tidak ekonomis, tidak dapat diprediksi, memakan waktu, dan tidak dapat menjelaskan hubungan yang terjadi. ${ }^{1}$ 
Untuk mengatasi kekurangan-kekurangan dari proses formulasi secara konvensional maka dikembangkan sebuah pendekatan baru yaitu dengan Experimental Design atau desain eksperimental yang merupakan teknik optimasi. Pada proses formulasi sediaan perlu dilakukan optimasi untuk menentukan formula terbaik dengan menggunakan data hasil evaluasi dari sediaan yang dibuat. Optimasi dapat diartikan sebagai pendekatan untuk mendapatkan kombinasi terbaik dari suatu produk atau karakteristik proses dibawah kondisi tertentu. Dapat juga diartikan sebagai memilih elemen atau bahan terbaik dari beberapa pilihan yang tersedia ${ }^{1}$. Data parameter-parameter evaluasi yang telah ditentukan diolah menggunakan berbagai macam metode. Pengolahan data dapat dilakukan lebih mudah menggunakan software. Data yang diolah adalah data prediksi dengan data yang dihasilkan setelah eksperimen. Salah satu software yang banyak digunakan adalah Design-Expert. ${ }^{2}$ Penggunaan Design-expert selain untuk formulasi obat-obat konvensional seperti tablet, kapsul juga digunakan untuk formulasi drug delivery system seperti tablet lepas lambat, targeted drug delivery seperti liposom, etosom, dan nano partikel. Penggunaannya tidak hanya sebatas bidang kefarmasian, tapi lebih dari itu contohnya dalam penelitian komposisi optimal campuran minyak nabati sebagai bahan baku sintesis biodiesel proses optimasinya menggunakan Design-Expert. ${ }^{2}$

Formulasi yang dibantu menggunakan Design-Expert lebih menguntungkan dikarenakan dalam tahapan di dalamnya telah tersedia panduan yang memberikan arahan dan dapat dipilih sesuai tujuan design of experiments (DOE) atau desain eksperimental yang akan dilakukan. Sehingga perlu dilakukan kajian pustaka sejauh mana pemanfaatan Design-Expert dalam formulasi.

\section{Metode}

Penyusunan kajian pustaka dimulai pada 4 April 2020, pencarian menggunakan Google scholar dan Scince Direct dengan kata kunci "Formulation" dan "Design-Expert" menghasilkan penemuan 63 artikel dan artikel yang masuk ke dalam kriteria inklusi sebanyak 51 artikel. Kriteria inklusi yang digunakan pada kajian pustaka ini yaitu jurnal penelitian formulasi dan optimasi menggunakan Design-Expert software, jurnal diterbitkan antara tahun 2011 sampai dengan April 2020. Kriteria eksklusi dalam kajian pustaka ini adalah publikasi artikel berbentuk review dan artikel optimasi diluar bidang keilmuan farmasi.

\section{Pembahasan}

\section{A. Design-Expert Software dalam optimasi Sediaan Farmasi}

Design-Expert adalah software metode statistik yang diproduksi oleh stateease. Software ini pertama kali dirilis tahun 1996 digunakan untuk membantu melakukan desain eksperimental seperti menentukan formula optimum suatu sediaan. Selain optimasi, software ini juga juga dapat menginterpretasikan faktor-faktor dalam percobaan. Dalam software ini terbagi menjadi tiga pilihan arah penelitian tergantung dengan desain percobaan yang akan dilakukan. Terdapat pilihan screening, characterization, dan optimization. ${ }^{3}$ 
Screening membutuhkan paling sedikit run tetapi memberikan informasi paling sedikit. Run adalah banyaknya eksperimen yang harus dilakukan sesuai dengan desain eksperimental yang dipilih. Screening digunakan jika memiliki banyak faktor yang memungkinkan $(>6)$, tetapi tidak diketahui mana yang memiliki efek nyata. Identifikasi beberapa faktor penting menggunakan hanya dua level dari masing-masing faktor dan perkiraan efek utama (tidak ada interaksi). Memerlukan tindak lanjut dengan DOE ke-2 untuk memperkirakan interaksi dan persyaratan yang lebih jauh Characterization memerlukan lebih banyak run per faktor, tetapi memberikan lebih banyak informasi. Digunakan hanya dengan beberapa faktor $(<10)$. Menentukan faktor mana yang memiliki pengaruh signifikan terhadap respons, termasuk interaksi di antaranya (cocok dengan model interaksi dua faktor). Perlu dipertimbangkan menambahkan titik tengah ke desain ini untuk mendeteksi interaksi non-linear jika telah mempersempit faktorfaktornya. Dengan adanya titik tengah, dapat digunakan untuk menemukan pengaturan faktor yang memaksimalkan atau meminimalkan respons jika tidak ada curves/lengkungan yang terdeteksi ${ }^{3}$.

Optimization membutuhkan paling banyak run per faktor, tetapi akan memberikan informasi terbanyak. Optimasi digunakan setelah mempersempit daftar faktor $(<6)$ yang diketahui penting dan kemungkinan optimumnya ada di wilayah yang sedang diuji. Dapat digunakan untuk menemukan pengaturan faktor yang memaksimalkan atau meminimalkan respons ${ }^{3}$.Dari tiga pilihan design of experiment tersebut, masing-masing di dalamnya terdapat tiga metode yang dapat digunakan, yaitu:

\section{Faktorial}

Desain faktorial merupakan aplikasi persamaan regresi untuk memberikan model hubungan antara variabel respon dengan satu atau lebih variabel bebas. Faktorial adalah jenis desain yang paling umum untuk perbaikan proses. Dalam penelitian, faktorial digunakan untuk mencari efek dari berbagai kondisi terhadap hasil dari penelitian dan juga digunakan untuk melihat interaksi didalamnya dikuantifikasi. ${ }^{4}$

Dalam desain fakorial terdapat faktor, level dan efek. Faktor diartikan sebagai besaran variabel independen yang akan mempengaruhi hasil output atau variabel dependen. Faktor dibedakan menjadi faktor kuantitatif (faktor yang bersifat numerikal. misal, konsentrasi 1\%, 2\%) dan kualitatif (factor non-numerikal. Misal, mutu/kualitas polimer). Level diartikan nilai atau tetapan untuk faktor. Efek adalah perubahan respon yang disebabkan variasi tingkat faktor. Respon diartikan sifat atau hasil percobaan yang diamati dan dapat dikuantifikasi. ${ }^{4}$

\section{Respon surface methodology (RSM)}

Respon surface methodology (RSM) merupakan metode yang diketahui juga dengan nama Box-Wilson Methodology. Respon surface methodology merupakan kumpulan teknik statistik dan matematika yang berguna untuk memodelkan dan menganalisis masalah-masalah dimana responnya dipengaruhi berbagai variable. ${ }^{5}$ 
Respon surface methodology menghubungkan sebuah respon atau variabel luaran (output) dengan data masukan (input) yang mempengaruhinya. Jika ditemukan suatu daerah dengan respon optimum, maka dibuat model untuk menghubungkan ke daerah tersebut sehingga analisis dapat dilakukan untuk mencapai daerah optimal. Dalam penggunaan RSM harus berurutan sesuai dengan prosedur. Ketika suatu kejadian fisik berada jauh dari titik optimum, maka model persamaan 1 digunakan. Proses optimasi dengan RSM dapat dilihat pada Gambar $1 .{ }^{5}$

$$
y=\beta_{0}+\beta_{1} x_{1}+\beta_{2} x_{2}+\ldots+\beta_{k} x_{k}+\varepsilon
$$

(persamaan 1)

Persamaan 1 merupakan model regresi linear multiple dengan dua variabel bebas. Variabel bebas ini disebut dengan regresor atau variabel pemprediksi. $\beta_{0}$ merupakan nilai intersep yang tetap. $\beta_{1} \beta_{2}$ merupakan koefisien regresi parsial dimana $\beta_{1}$ mengukur perubahan y setiap perubahan unit $x 1$ begitu pula $\beta_{2}$ mengukur perubahan y setiap perubahan unit $x_{2}$. Model persamaan ini akan mendekatkan peneliti pada daerah optimum melalui jalur pengoptimasian. Setelah daerah optimum ditemukan maka model kedua atau persamaan 2 digunakan. ${ }^{5}$

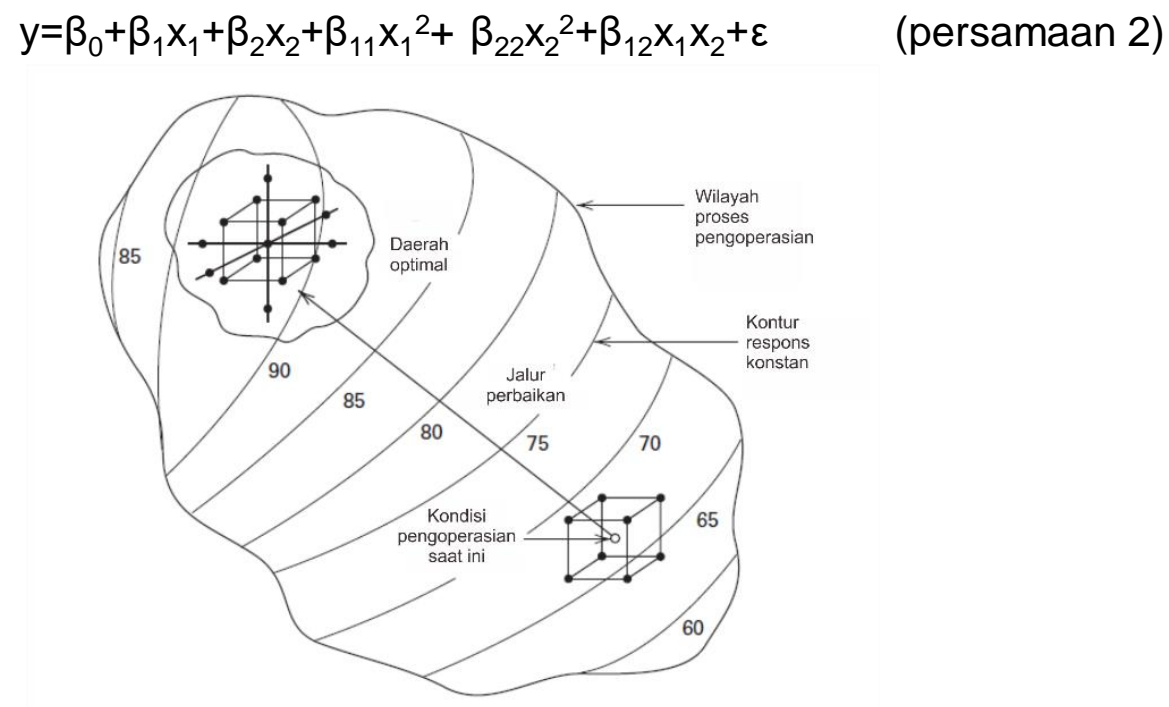

Gambar 1. Proses optimasi dengan RSM (5)

Tahapan optimasi dilanjutkan dengan menganalisis permukaan respon untuk mendapatkan titik optimum. Analisis dilakukan dengan menggunakan permukaan respon yang cocok. Jika permukaan yang cocok merupakan perkiraan dari fungsi respon yang sesungguhnya maka analisis permukaan yang cocok ini akan sebanding dengan sistem yang sesungguhnya. Parameter modelnya dapat diperkirakan secara efektif jika desain eksperimental yang digunakan untuk mengumpulkan data menggunakan desain eksperimental yang tepat. ${ }^{5}$ 
Respon surface design atau desain permukaan respon merupakan desain untuk mencocokan permukaan respon. Pencocokan menggunakan desain yang berbeda untuk setiap modelnya. Dalam RSM terdapat dua desain yaitu:

\section{a. Central Composite Design (CCD)}

Central composite design dalam proses optimasi dilakukan untuk mengetahui perkiraan arah optimal karena dalam RSM optimasi dan lokasi optimal tidak diketahui. Selain itu pada CCD memiliki rotatability atau pada titik $x$ yang berada pada jarak yang sama akan memiliki $(\mathrm{y}(\mathrm{x}))$ yang sama sehingga penting untuk dilakukan. Titik uji yang dalam CCD diambil berdasarkan nilai batas uji yang ditentukan untuk masing-masing faktor penelitian. Data respon yang diperoleh dimodelkan oleh model matematika yang sesuai. Dalam CCD terdapat beberapa model yaitu mean, linier, quadratic, 2 factor interaction (2FI), dan cubic. Kriteria pemilihan model respon sama seperti pada pemilihan model dalam mixture design. Penentuan titik optimum dilihat dari nilai desaribility yang dihasilkan. Desirability menunjukan seberapa terpenuhi atau mendekati oleh titik optimum. Nilai desirability mendekati 1 adalah nilai yang diharapkan. Titik optimum yang baik memiliki desirability yang tinggi atau mendekati 1.5

\section{b. Box-Bhenken Design (BBD)}

Box-Bhenken Design (BBD) digunakan untuk optimasi dengan tiga variabel independen. Perbedaan Box-Bhenken Design (BBD) dengan Central Composite Design (CCD) adalah pada rancangan Box-Bhenken Design percobaanya lebih efisien karena sedikit run/unit percobaan dibandingkan dengan Central Composite Design. ${ }^{6}$ Walaupun jumlah run yang lebih sedikit tetapi Box-Bhenken mampu memprediksi nilai optimum baik linier maupun kuadratik dengan baik. ${ }^{7}$

\section{Mixture}

Mixture digunakan untuk komponen dalam formulasi yang berubah secara proporsional satu sama lain. Persentase setiap variabel harus selalu bertambah hingga mendapatkan nilai total tetap. Bahkan jika ada komponen variabel dalam jumlah yang sangat kecil, tetap dapat digunakan karena metode ini menunjukkan respons yang sangat sensitif terhadap bahan-bahan tersebut. Contoh: Ilmuan makanan bereksperimen pada campuran buah yang terdiri dari jus semangka, nanas dan jeruk, dan air. Respons tergantung pada proporsi berbagai buah, bukan jumlah total campuran. Jika jumlah setiap bahan digandakan, rasanya tetap sama. ${ }^{5}$

Nilai faktor dalam mixture design memiliki proporsi antara 0 dan 1. Salah satu metode dalam mixture design adalah simplex lattice design (SLD). Simplex lattice design adalah metode optimasi yang digunakan untuk menentukan formula optimum suatu campuran bahan dengan proporsi jumlah total suatu bahan yang berbeda harus 1 (100\%). Bahan atau faktor yang digunakan dalam optimasi adalah minimal terdiri dari dua bahan yang berbeda. Faktor dalam mixture design akan menetukan ruang desain atau daerah uji. ${ }^{5}$ 
Daerah uji pada setiap faktor dibatasi sesuai batasan banyaknya bahan yang bisa digunakan pada setiap faktornya. Batas yang digunakan adalah batas minimal dan batas maksimal pada setiap faktor. Berdasar daerah uji tersebut, software akan menetukan titik uji pada formula. Software akan menggunakan the verticles, the edge centers, the overall centroid, dan the checkruns sebagai titik ujinya. Dalam penentuan titik ini pada beberapa titik akan mengalami pengulangan atau replicated untuk mendapatkan nilai pure error. Selanjutnya, respon yang didapatkan akan digambarkan oleh contour plot atau plot kontur. Dengan adanya plot kontur, titik optium dapat dicapai dengan presisi. ${ }^{5}$

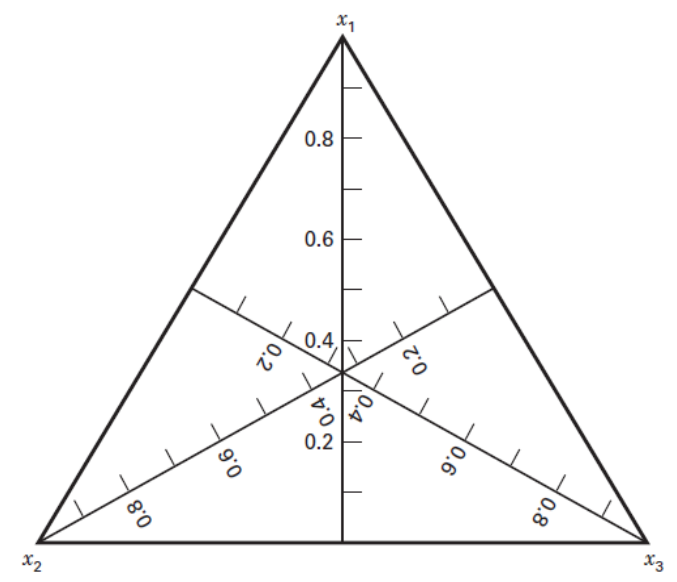

Gambar 2. Daerah uji mixture design dengan tiga faktor ${ }^{5}$

Pemodelan data dilakukan menggunakan model matematika, untuk mixture design terdapat empat model matematika yaitu linear, quadratic, cubic, special cubic. Model dipilih berdasarkan beberapa kriteria yaitu signifikansi model, signifikansi lack of fit, adjustedr-square, dan predicted r-square pada saat analisis ANOVA. Model dipilih apabila memiliki probabilitas model dan probabilitas lack of fit kurang dari nilai a (5\%) yang berarti model tersebut berpengaruh secara signifikan terhadap respon pada tahap signifikansi $5 \% .^{5}$

Mixture Design dapat memberikan formula optimal dengan menggunakan data respon dari parameter-parameter masing-masing sediaan. Dari berbagai variasi formula campuran, formula optimum merupakan formula memiliki hasil evaluasi berada dalam rentang batas dalam setiap parameter. Lalu dilihat menggunakan derajat desirability, formula yang memiliki derajat desirability mendekati 1 merupakan formula terbak/optimum.

Dari artikel dalam penelitian Damayanti et al., ${ }^{8}$ sediaan memiliki hasil optimal dengan tingkat desirability mendekati 1. Hasil tersebut menunjukan Mixture Design dapat digunakan untuk optimasi formula dengan taraf kepercayaan yang tinggi. 


\section{Combined}

Combined atau kombinasi adalah design of experiment (DOE) kombinasi antara factorial, RSM dengan mixture. Digunakan untuk mempelajari variabel-variabel antara variabel komposisi campuran dan variabel proses dalam satu DOE. ${ }^{3}$

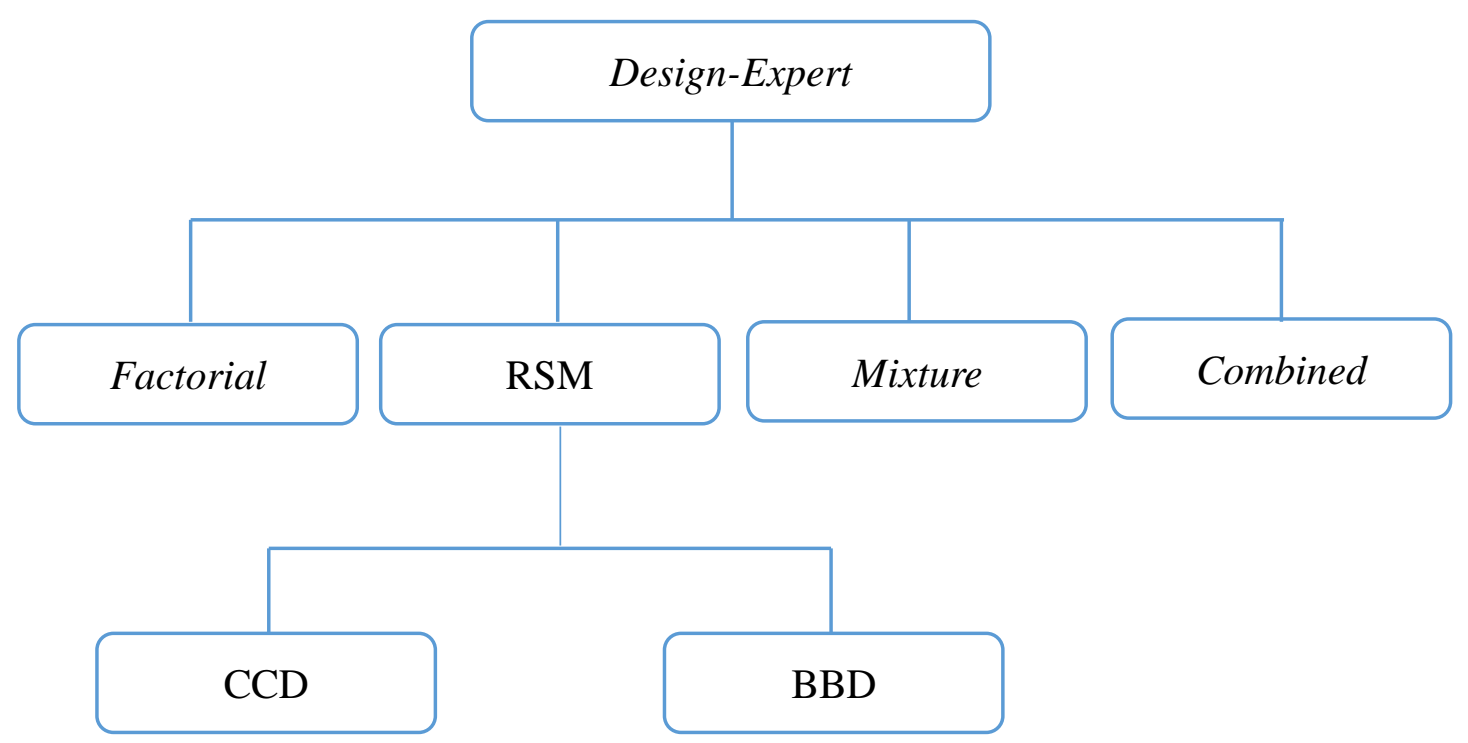

Gambar 3. Bagan Metode dalam Design-Expert ${ }^{3}$

B. Penggunaan Design-Expert dalam formulasi sediaan Liquid, Semi solid, dan Solid

Menurut Peraturan Pemerintah RI No. 51 tahun 2009, sediaan farmasi dibagi menjadi 3 berdasarkan konsistensinya, yaitu cair atau liquid, semi padat atau semi solid dan padat atau solid. Sediaan liquid adalah sediaan dengan wujud cair yang mengandung satu atau lebih zat aktif terlarut atau terdispersi homogen didalamnya. Sediaan semi solid adalah sediaan yang mampu kemampuan untuk melekat pada permukaan tempat pemakaian dalam waktu yang cukup lama.

Sediaan solid aadalah sediaan berbentuk padat, kering, dan mengandung satu atau lebih zat aktif yang tercampur homogen. Setiap sediaan farmasi memiliki standar baku yang dipersyaratkan untuk mendapatkan formula optimal sediaan. Untuk menentukan formula optimal diperlukan studi formulasi dan eksperimental dalam laboratorium. Dalam studi formulasi terbaru, tahap eksperimental dapat dipermudah dengan bantuan software untuk mendapatkan formula optimal. Software yang dapat digunakan adalah Design-Expert Software. Berikut merupakan artikel penelitian yang berhasil mendapatkan formula optimal menggunakan Design-Expert Software. Yang dicantumkan dalam tabel 1. 
Tabel 1. Sediaan Liquid, Semi Solid, dan Solid yang Dioptimasi dengan Design-Expert

\section{Variabel optimasi}

\begin{tabular}{|l|l|r|} 
No & Zat aktif & Sed \\
\hline 1 & $\begin{array}{l}\text { Fraksi Bunga } \\
\text { Kembang } \\
\text { Sepatu } \\
\text { (Hibiscus rosa- } \\
\text { sinensis L.) }\end{array}$ \\
\hline
\end{tabular}

2 Siprofloksasin Suspensi

Factoria Variabel
independent

Variabel dependen

Pustaka design

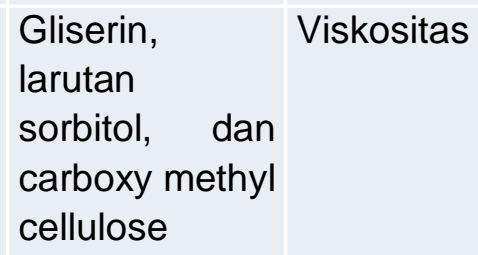

Gliserin,

Viskositas larutan

sorbitol, dan carboxy methyl cellulose (CMC-Na)

$\begin{array}{ll}\text { design } & \begin{array}{l}\text { larutan } \\ \text { sorbitol, dan } \\ \text { carboxy methyl } \\ \text { cellulose }\end{array}\end{array}$

Carbopol 934 Viskositas, dan Pulvis volume gummi arabici sedimentasi, (PGA) dan redispersibilitas

3 Ibuprofen

Gel

Mixture

Propilen Glikol pH, viskositas, design dan penyebaran gel

4 Oksibenzon dan Krim Titanium Dioksida

Mixture design

Trietanolamin Viskositas, (TEA) stearat daya sebar, dan setil dan daya lekat alcohol

5 Ekstrak Pacing Tablet

Mixture

Avicel PH 200 Friabilitas dan (Costus design dan Amylum waktu hancur speciosus)

$6 \begin{array}{lll}\text { Levocetirizine } & \text { Tablet } \\ \text { hydrochloride } & \text { sublingual }\end{array}$ dan ambroxol

Central

Sodium starch Waktu hancur hydrochloride composite glycolate dan rasio design (SSG) dan penyerapan air Camphor

7 Montelukast Orally Response Crospovidone Friabilitas dan sodium disintegratin surface dan sodium waktu hancur g tablets methodology bicarbonate (ODT)

8 Ketoprofen Tablet salut $3^{2}$ factorial Hydroxypropyl Lag time dan design methylcellulos Persentase e (HPMC) pelepasan K4M dan SSG obat. 
Tabel 1. Sediaan Liquid, Semi Solid, dan Solid yang Dioptimasi dengan Design-Expert (lanjutan)

\begin{tabular}{|c|c|c|c|c|c|c|}
\hline \multirow[b]{2}{*}{ No } & \multirow[b]{2}{*}{ Zat aktif } & \multirow[b]{2}{*}{ Sediaan } & \multirow[b]{2}{*}{ Metode } & \multicolumn{2}{|c|}{ Variabel optimasi } & \multirow[b]{2}{*}{ Pustaka } \\
\hline & & & & $\begin{array}{l}\text { Variabel } \\
\text { independent }\end{array}$ & $\begin{array}{l}\text { Variabel } \\
\text { dependen }\end{array}$ & \\
\hline 9 & Aceclofenac & Tablet & $\begin{array}{l}\text { Respon } \\
\text { Surface } \\
\text { Methodology }\end{array}$ & $\begin{array}{l}\text { Avicel PH 102, } \\
\text { Magnesium } \\
\text { Stearate, dan } \\
\text { AcDiSol }\end{array}$ & $\begin{array}{l}\text { Variasi berat, } \\
\text { kerapuhan, } \\
\text { disintegrasi } \\
\text { dan disolusi. }\end{array}$ & (16) \\
\hline 10 & $\begin{array}{l}\text { Ekstrak daun } \\
\text { Ivy (Hedera } \\
\text { helix) }\end{array}$ & Tablet & $\begin{array}{l}\text { Respon } \\
\text { Surface } \\
\text { Methodology }\end{array}$ & 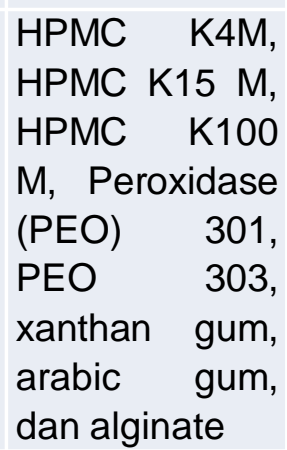 & Disolusi & (17) \\
\hline 11 & Diclofenac & $\begin{array}{l}\text { Buccal } \\
\text { tablets }\end{array}$ & $\begin{array}{l}\text { Factorial } \\
\text { design }\end{array}$ & $\begin{array}{l}\text { Karbopol dan } \\
\text { Chitosan }\end{array}$ & $\begin{array}{l}\text { Waktu } \\
\text { disintegrasi, } \\
\text { kapasitas } \\
\text { pembengkakan } \\
\text {, disolusi, gaya } \\
\text { detasemen } \\
\text { puncak dan } \\
\text { permeabilitas }\end{array}$ & (18) \\
\hline 12 & Repaglinide & $\begin{array}{l}\text { Floating } \\
\text { tablets }\end{array}$ & $\begin{array}{l}\text { Factorial } \\
\text { (three full } \\
\text { level factorial } \\
\text { design) }\end{array}$ & $\begin{array}{l}\text { Okra gum } \\
\text { (OG), HPMC } \\
\text { K15M, } \\
\text { Xanthan gum }\end{array}$ & $\begin{array}{l}\text { Floating lag } \\
\text { time dan } \\
\text { swelling index }\end{array}$ & (19) \\
\hline 13 & $\begin{array}{l}\text { Losartan } \\
\text { Potassium }\end{array}$ & $\begin{array}{l}\text { Tablet } \\
\text { lepas } \\
\text { lambat }\end{array}$ & $\begin{array}{l}\text { Response } \\
\text { Surface } \\
\text { Methodology }\end{array}$ & $\begin{array}{l}\text { HPMC K4M, } \\
\text { etil selulosa, } \\
\text { dan natrium } \\
\text { karboksi metil } \\
\text { selulosa }\end{array}$ & $\begin{array}{l}\text { Persentase } \\
\text { pelepasan obat }\end{array}$ & (20) \\
\hline 14 & Risperidone & $\begin{array}{l}\text { Tablet } \\
\text { sublingual }\end{array}$ & $\begin{array}{l}\text { Factorial } \\
\text { design }\end{array}$ & $\begin{array}{l}\text { SSG dan } \\
\text { selulosa } \\
\text { mikrokristalin }\end{array}$ & $\begin{array}{l}\text { Waktu hancur } \\
\text { dan } \\
\text { Persentase } \\
\text { pelepasan obat }\end{array}$ & (21) \\
\hline 15 & $\begin{array}{l}\text { Ekstrak Herba } \\
\text { Pegagan } \\
\text { (Centella } \\
\text { asiatica) dan } \\
\text { Herba } \\
\text { sambiloto } \\
\text { (Andrographis } \\
\text { paniculata) }\end{array}$ & Granul & $\begin{array}{l}\text { Factorial } \\
\text { design }\end{array}$ & $\begin{array}{l}\text { Avicel PH } 101 \\
\text { dan Polyvinyl } \\
\text { pyrrolidone } \\
\text { (PVP) K-30 }\end{array}$ & $\begin{array}{l}\text { Kecepatan alir, } \\
\text { daya serap, } \\
\text { kelembaban } \\
\text { dan indeks } \\
\text { pengetapan }\end{array}$ & (22) \\
\hline
\end{tabular}


Artikel penelitian optimasi sediaan farmasi konvensional seperti tablet, sirup, krim, gel, tidak banyak ditemukan dikarenakan arah pengembangan obat baru lebih memilih drug delivery untuk menghindri kekurangan-kekurangan yang terjadi pada sediaan konvensional. Namun demikian, ditemukan beberpa artikel pengembangan obat konvensional yang diabantu oleh Design-Expert software. Dalam penelitian $\mathrm{Na}$ et al, ${ }^{17}$ Design-Expert software digunakan untuk menentukan formula optimal. Metode yang digunakan yaitu RSM dikarenakan variabel independen yang digunakan cukup banyak. Variabel tersebut adalah polimer HPMC K4M, HPMC K15 M, HPMC K100 M, Peroxidase (PEO) 301, PEO 303, xanthan gum, arabic gum, dan alginate. Menggunakan metode RSM dapat diketahui variabel yang memiliki pengaruh signifikan untuk mendapatkan formula optimal, sehingga didapatkan tablet yang memiliki kualitas sesuai standar baku yang dinilai yaitu dari disolusi tablet yang dihasilkan.

Penelitian Murrukhmihadi, ${ }^{9}$ dan Damayanti, ${ }^{8}$ optimasi formula dilakukan dengan menggunakan metode Mixture design. Optimasi formula dengan menggunakan metode mixture design memiliki keuntungan jumlah run formula lebih sedikit dibandingkan dengan factorial maupun RSM. Jumlah run lebih sedikit artinya waktu yang dibutuhkan lebih sedikit untuk experimental dalam laboratorium sehingga lebih efisien waktu mauapun bahan. Metode ini cocok digunakan untuk penelitian skripsi dan desertasi yang memiliki waktu terbatas.

Dalam Tabel 1 terdapat penelitian optimasi formulasi dengan zat aktif bahan alam. Formulasi menggunakan zat aktif bahan alam memerlukan pemilihan perhitungan komposisi yang tepat. Hal ini dikarenakan zat aktif bahan alam memiliki karakteristik yang berbeda, seperti higroskopis yang akan mempengaruhi kestabilan sediaan. Penelelitian $\mathrm{Na}$ et al, ${ }^{17}$ berhasil mendapatkan formula optimal tablet dengan persen error sebesar 0.36. Nilai tersebut membuktikan pemilihan metode RSM sudah tepat untuk foemulasi dengan variabel independen berupa HPMC K4M, HPMC K15 M, HPMC K100 M, Peroxidase (PEO) 301, PEO 303, xanthan gum, arabic gum, dan alginate. RSM untuk menemukan formula optimum dan untuk mengetahui interaksi antar faktor yaitu variabel independen. Interaksi pada setiap variabel digunakan untuk memprediksi formula optimum dengan menggunakan perhitungan matematika dalam software. Selanjutnya dilakukan eksperimen dalam laboratorium (wet lab). Variabel independen akan mempengaruhi hasil pada variabel dependen. Nilai dari variabel dependen yang digunakan untuk mendapatkan formula optimal dan dibandingkan hasil eksperimen sesungguhnya dengan hasil prediksi software dan digunakan untuk menghitung persen error.

\section{Penggunaan Design-Expert dalam formulasi Drug Delivery System}

Penggunaan Design-Expert software tidak terbatas pada formulasi sediaan kovensional seperti tablet, sirup, emulsi. Telah banyak penelitian mengenai pengembangan obatabatan drug delivery system dengan dibantu oleh Design-Expert software. Drug delivery system adalah formulasi obat atau alat ke dalam tubuh dengan meningkatkan efektivitas dan keamanan obat dengan mengontrol laju, waktu, dan tempat lepas obat di dalam tubuh. ${ }^{23}$ 
Drug delivery system dalam kajian pustaka ini meliputi Transdermal Delivery (TDDs), Gel In Situ, Ocular Insert, dan Self-nanoemulsifying Drug Delivery System (SNEDDs). Transdermal Delivery (TDDs) merupakan pengembangan penghantaran obat untuk menghindari first pass effect dan side effect atau efek samping yang terjadi pada obat konvensional rute oral. ${ }^{24} \mathrm{Gel}$ In Situ merupakan system gel yang diaplikasikan dalam bentuk cairan, lalu akan berubah menjadi gel di tempat pengaplikasian. ${ }^{25}$ Ocular Insert adalah sediaan yang disisipkan ke belakang kelopak mata atau ke atas mata dengan bentuk solid maupun semi solid. Sediaan ini merupakan sediaan steril yang memiliki efek topikal atau sistemik. ${ }^{26}$ Self-nanoemulsifying Drug Delivery System (SNEDDs) merupakan sediaan farmasi berbasis minyak. Sediaan ini merupakan campuran isotropik antara minyak, surfaktan, dan ko-surfaktan yang dapat membentuk emulsi ketika terjadi kontak dengan asam lambung. ${ }^{27}$

Tabel 2. Drug Delivery System yang Dioptimasi dengan Design-Expert

\begin{tabular}{|c|c|c|c|c|c|c|}
\hline \multirow[b]{2}{*}{ No } & \multirow[b]{2}{*}{ Zat aktif } & \multirow[b]{2}{*}{ Sediaan } & \multirow[b]{2}{*}{ Metode } & \multicolumn{2}{|c|}{ Variabel optimasi } & \multirow[b]{2}{*}{ Pustaka } \\
\hline & & & & $\begin{array}{l}\text { Variabel } \\
\text { independen }\end{array}$ & $\begin{array}{l}\text { Variabel } \\
\text { dependen }\end{array}$ & \\
\hline 1 & Buprenorphine & $\begin{array}{l}\text { Transderma } \\
\text { I Delivery }\end{array}$ & $\begin{array}{l}\text { Response } \\
\text { Surface } \\
\text { Methodology } \\
\text { (Box-Bhenken } \\
\text { Design) }\end{array}$ & $\begin{array}{l}\text { Asam levulinic } \\
\text { (LEV), } \quad \text { lauryl } \\
\text { alkohol (LA), dan } \\
\text { Tween } 80(\mathrm{~T})\end{array}$ & $\begin{array}{l}\text { Permeasi kulit, } \\
\text { nilai tack, dan } \\
\text { kekuatan kulit. }\end{array}$ & (28) \\
\hline 2 & Avanafil (AVA) & $\begin{array}{l}\text { Transderma } \\
\text { I Delivery }\end{array}$ & $\begin{array}{l}\text { Response } \\
\text { Surface } \\
\text { Methodology } \\
\text { (Box-Bhenken } \\
\text { Design) }\end{array}$ & $\begin{array}{l}\text { Fosfolipid, etanol, } \\
\text { terpene, dan tipe } \\
\text { terpene }\end{array}$ & $\begin{array}{l}\text { Ukuran vesikel } \\
\text { dan efisiensi } \\
\text { penjeratan AVA }\end{array}$ & (29) \\
\hline 3 & Insulin & $\begin{array}{l}\text { Transderma } \\
\text { I Delivery }\end{array}$ & Factorial design & $\begin{array}{lr}\text { Rasio lipid, } & \text { rasio } \\
\text { lipid } & \text { dan } \\
\text { surfaktan, } & \text { rasio } \\
\text { surfaktan } & \end{array}$ & $\begin{array}{l}\text { Aliran } \\
\text { penyerapan } \\
\text { (permeation flux) }\end{array}$ & (30) \\
\hline 4 & Rivastigmine & $\begin{array}{l}\text { Transderma } \\
\text { I Delivery }\end{array}$ & $\begin{array}{l}\text { Response } \\
\text { Surface } \\
\text { Methodology } \\
\text { (Box-Bhenken } \\
\text { Design) }\end{array}$ & $\begin{array}{lr}\text { Trasio lipid padat } \\
\text { dan cair, rasio } \\
\text { surfaktan dan } \\
\text { siklus } \\
\text { Pressure } \\
\text { Homogenization } \\
(\mathrm{HPH})\end{array}$ & $\begin{array}{l}\text { Ukuran partikel, } \\
\text { indeks } \\
\text { polidispersitas } \\
\text { (PDI), potensi } \\
\text { zeta (ZP) dan } \\
\text { Efisiensi } \\
\text { enkapsulasi (EE) }\end{array}$ & (31) \\
\hline 5 & Paeonol & $\begin{array}{l}\text { Transderma } \\
\text { I Delivery }\end{array}$ & $\begin{array}{l}\text { Central } \\
\text { composite design }\end{array}$ & $\begin{array}{l}\text { Etanol, kolesterol } \\
\text { (CHO) dan kedelai } \\
\text { fosfatidilkolin } \\
\text { (SPC) }\end{array}$ & $\begin{array}{l}\text { EE, ukuran } \\
\text { vesikel (VS), ZP } \\
\text { dan PDI }\end{array}$ & (32) \\
\hline 6 & Ibuprofen & $\begin{array}{l}\text { Transderma } \\
\text { I Delivery }\end{array}$ & Mixture design & $\begin{array}{lr}\text { Perekat silikon } \\
\text { BIO-PSA } & 7-4302, \\
\text { perekat polyacrylic } \\
\text { DuroTak 387- } \\
\text { 2287, oleylalcohol } \\
\text { dan ibuprofen }\end{array}$ & $\begin{array}{l}\text { Kelekatan, } \\
\text { adhesi geser, } \\
\text { pembentukan } \\
\text { kristal, ukuran } \\
\text { tetesan dan } \\
\text { ukuran tetesan } \\
\text { rata-rata }\end{array}$ & (33) \\
\hline
\end{tabular}


Table 2. Drug Delivery System yang Dioptimasi dengan Design-Expert (lanjutan)

\begin{tabular}{|c|c|c|c|c|c|c|}
\hline \multirow[b]{2}{*}{ No } & \multirow[b]{2}{*}{ Zat aktif } & \multirow[b]{2}{*}{ Sediaan } & \multirow[b]{2}{*}{ Metode } & \multicolumn{2}{|c|}{ Variabel optimasi } & \multirow[b]{2}{*}{ Pustaka } \\
\hline & & & & $\begin{array}{l}\text { Variabel } \\
\text { independen }\end{array}$ & $\begin{array}{l}\text { Variabel } \\
\text { dependen }\end{array}$ & \\
\hline 7 & $\begin{array}{l}\text { Anti-rheumatic } \\
\text { dexibuprofen }\end{array}$ & $\begin{array}{l}\text { Transdermal } \\
\text { Delivery }\end{array}$ & $\begin{array}{l}\text { Response } \\
\text { Surface } \\
\text { Methodology } \\
\text { (Box-Bhenken } \\
\text { Design) }\end{array}$ & $\begin{array}{l}\text { Matriks } \\
\text { Polimer, } \\
\text { Plasticizer, di- } \\
\text { N-butyl } \\
\text { phthalate, dan } \\
\text { minyak } \\
\text { Almond. }\end{array}$ & $\begin{array}{l}\text { Fluks } \\
\text { keadaan } \\
\text { stabil (fluks } \\
\text { steady state), } \\
\text { Lag time, } \\
\text { Koefisien } \\
\text { permeabilitas } \\
\text { (kp) }\end{array}$ & (34) \\
\hline 8 & Ketoprofen & $\begin{array}{l}\text { Transdermal } \\
\text { Delivery }\end{array}$ & $\begin{array}{l}\text { Simplex lattice } \\
\text { design }\end{array}$ & $\begin{array}{l}\text { Fase minyak, } \\
\text { fase } \\
\text { pengemulsi } \\
\text { dan fase air }\end{array}$ & $\begin{array}{l}\text { VS, EE, fluks } \\
\text { transdermal }\end{array}$ & (35) \\
\hline 9 & $\begin{array}{l}\text { Ketorolac } \\
\text { tromethamine }\end{array}$ & $\begin{array}{l}\text { Transdermal } \\
\text { Delivery }\end{array}$ & $\begin{array}{l}\text { Central } \\
\text { composite } \\
\text { design }\end{array}$ & $\begin{array}{l}\text { Karbopol } 940 \\
\text { dan } \\
\text { polyethylene } \\
\text { glycol (PEG) } \\
400\end{array}$ & $\begin{array}{l}\% \quad \text { Permeasi } \\
\text { obat kumulatif }\end{array}$ & (36) \\
\hline 10 & $\begin{array}{l}\text { Olmesartan } \\
\text { medoxomil }\end{array}$ & $\begin{array}{l}\text { Transdermal } \\
\text { Delivery }\end{array}$ & $\begin{array}{l}\text { Box-Behnken } \\
\text { design }\end{array}$ & $\begin{array}{l}\text { Fosfolipid, } \\
\text { etanol, dan b- } \\
\text { sitronelena, }\end{array}$ & $\begin{array}{l}\text { VS, EE, fluks } \\
\text { transdermal }\end{array}$ & (37) \\
\hline 11 & $\begin{array}{l}\text { Rosuvastatin- } \\
\text { Ellagic Acid }\end{array}$ & Gel In Situ & $\begin{array}{l}\text { Response } \\
\text { Surface } \\
\text { Methodology } \\
\text { (Box-Bhenken } \\
\text { Design) }\end{array}$ & $\begin{array}{l}\text { Lesitin, Tween } \\
80 \text {, dan d- } \\
\text { tokoferol } \\
\text { polietilen glikol } \\
\text { suksinat } \\
\text { (TPGS) }\end{array}$ & $\begin{array}{l}\text { Ukuran } \\
\text { partikel, } \\
\text { penjeratan, } \\
\text { dan stabilitas. }\end{array}$ & (25) \\
\hline 12 & $\begin{array}{l}\text { Fluconazole- } \\
\text { hydroxypropyl } \\
\text {-beta- } \\
\text { cyclodextrin } \\
\text { complex }\end{array}$ & Gel In Situ & $\begin{array}{l}\text { Factorial } \\
\text { design }\end{array}$ & $\begin{array}{l}\text { Eudragit dan } \\
\text { polimer }\end{array}$ & $\begin{array}{l}\text { Ukuran } \\
\text { partikel, } \\
\text { potensial zeta } \\
\text { dan EE \%. }\end{array}$ & (38) \\
\hline 13 & $\begin{array}{l}\text { Midazolam } \\
\text { hydrochloride }\end{array}$ & Gel In Situ & $\begin{array}{l}\text { Factorial } \\
\text { design }\end{array}$ & $\begin{array}{l}\text { Gellan gum } \\
\text { dan karbopol } \\
934\end{array}$ & $\begin{array}{l}\text { Viskositas } \\
\text { kondisi non- } \\
\text { fisiologis, } \\
\text { Viskositas } \\
\text { kondisi } \\
\text { fisiologis. }\end{array}$ & (39) \\
\hline 14 & Ciprofloxacin & Gel In Situ & $\begin{array}{l}\text { Response } \\
\text { Surface } \\
\text { Methodology } \\
\text { (Box-Bhenken } \\
\text { Design) }\end{array}$ & $\begin{array}{l}\text { Phytantriol, } \\
\text { Lutrol, dan pH } \\
\text { media hidrasi. }\end{array}$ & $\begin{array}{l}\text { Ukuran } \\
\text { partikel, } \\
\text { enkapsulasi, } \\
\text { dan fluks } \\
\text { steady state. }\end{array}$ & $(40)$ \\
\hline
\end{tabular}


Table 2. Drug Delivery System yang Dioptimasi dengan Design-Expert (lanjutan)

\begin{tabular}{|c|c|c|c|c|c|c|}
\hline \multirow{3}{*}{$\begin{array}{l}\text { No } \\
15\end{array}$} & \multirow{3}{*}{$\begin{array}{l}\text { Zat aktif } \\
\text { Bimatoprost } \\
\text { solid lipid } \\
\text { nanoparticles }\end{array}$} & \multirow[b]{2}{*}{ Sediaan } & \multirow{3}{*}{$\begin{array}{l}\text { Metode } \\
\text { Factorial } \\
\text { design }\end{array}$} & \multicolumn{2}{|c|}{ Variabel optimasi } & \multirow[b]{2}{*}{ Pustaka } \\
\hline & & & & $\begin{array}{l}\text { Variabel } \\
\text { independen }\end{array}$ & $\begin{array}{l}\text { Variabel } \\
\text { dependen }\end{array}$ & \\
\hline & & $\begin{array}{l}\text { Gel } \\
\text { Situ }\end{array}$ & & $\begin{array}{l}\text { Glyceryl } \\
\text { monostearate } \\
\text { (GMS) dan } \\
\text { Tween } 80\end{array}$ & $\begin{array}{l}\text { Ukuran partikel, } \\
\text { PDI, ZP dan EE }\end{array}$ & (41) \\
\hline 16 & Lorazepam & $\begin{array}{l}\text { Gel } \\
\text { Situ }\end{array}$ & $\begin{array}{l}\text { Factorial } \\
\text { design }\end{array}$ & $\begin{array}{l}\text { Minyak dan } \\
\text { gellan gum. }\end{array}$ & $\begin{array}{l}\text { Pelepasan obat } \\
\text { dan viskositas }\end{array}$ & $(42)$ \\
\hline 17 & Alendronate & $\begin{array}{l}\text { Gel } \\
\text { Situ }\end{array}$ & $\begin{array}{l}\text { Factorial } \\
\text { design }\end{array}$ & $\begin{array}{l}\text { Polimer PF- } \\
127 \quad \text { dan } \\
\text { polimer PF-68. }\end{array}$ & \begin{tabular}{lr}
\multicolumn{2}{l}{ Temperatur } \\
gelasi, waktu \\
gelasi, uji jarum \\
suntik, \\
persen \\
$\begin{array}{l}\text { pelepasan } \\
\text { kumulatif }\end{array}$
\end{tabular} & (43) \\
\hline 18 & Ropinirole & $\begin{array}{l}\text { Gel } \\
\text { Situ }\end{array}$ & $\begin{array}{l}\text { Factorial } \\
\text { design }\end{array}$ & $\begin{array}{l}\text { Polimer PF } \\
127 \quad \text { dan } \\
\text { HPMC K4M. }\end{array}$ & $\begin{array}{l}\text { Persentase } \\
\text { pelepasan obat, } \\
\text { suhu gelasi dan } \\
\text { kekuatan } \\
\text { mukoadhesif }\end{array}$ & (44) \\
\hline 19 & $\begin{array}{l}\text { Sumatriptan } \\
\text { succinate }\end{array}$ & $\begin{array}{l}\text { Gel } \\
\text { Situ }\end{array}$ & $\begin{array}{l}\text { Factorial } \\
\text { design }\end{array}$ & $\begin{array}{l}\text { Gellan gum } \\
\text { dan } \\
\text { polyethylene } \\
\text { glycol (PEG) } \\
400\end{array}$ & $\begin{array}{l}\text { Viskositas, } \\
\text { kekuatan } \\
\text { mukoadhesif, } \\
\text { persen } \\
\text { pelepasan obat } \\
\text { kumulatif }\end{array}$ & (45) \\
\hline 20 & $\begin{array}{l}\text { Moxifloxacin } \\
\text { hydrochloride }\end{array}$ & $\begin{array}{l}\text { Gel } \\
\text { Situ }\end{array}$ & $\begin{array}{l}\text { Factorial } \\
\text { design }\end{array}$ & $\begin{array}{l}\text { Polimer PF68 } \\
\text { dan Gelrite }\end{array}$ & $\begin{array}{l}\text { Suhu gelasi, } \\
\text { kekuatan gel, } \\
\text { gaya bioadhesi, } \\
\text { viskositas dan } \\
\text { pelepasan obat }\end{array}$ & $(46)$ \\
\hline 21 & $\begin{array}{l}\text { Brimonidine } \\
\text { tartrate }\end{array}$ & $\begin{array}{l}\text { Ocular } \\
\text { Insert }\end{array}$ & $\begin{array}{l}\text { Response } \\
\text { surface } \\
\text { methodology }\end{array}$ & $\begin{array}{l}\text { Cellulose } \\
\text { acetate } \\
\text { butyrate } \\
\text { (CAB) dan } \\
\text { PEG-600 }\end{array}$ & $\begin{array}{l}\text { Pelepasan obat, } \\
\text { konstanta laju } \\
\text { orde pertama } \\
\text { dan } 50 \%\end{array}$ & $(47)$ \\
\hline 22 & $\begin{array}{l}\text { Besifloxacin } \\
\text { hydrochloride }\end{array}$ & $\begin{array}{l}\text { Ocular } \\
\text { Insert }\end{array}$ & $\begin{array}{l}\text { Factorial } \\
\text { design }\end{array}$ & $\begin{array}{l}\text { Rasio lipid dan } \\
\text { rasio obat } \\
\text { terhadap lipid }\end{array}$ & $\begin{array}{l}\text { EE, pemuatan } \\
\text { obat dan ukuran } \\
\text { partikel }\end{array}$ & (48) \\
\hline
\end{tabular}


Table 2. Drug Delivery System yang Dioptimasi dengan Design-Expert (lanjutan)

\begin{tabular}{|c|c|c|c|c|c|c|}
\hline \multirow[b]{2}{*}{ No } & \multirow[b]{2}{*}{ Zat aktif } & \multirow[b]{2}{*}{ Sediaan } & \multirow[b]{2}{*}{ Metode } & \multicolumn{2}{|c|}{ Variabel optimasi } & \multirow[b]{2}{*}{ Pustaka } \\
\hline & & & & $\begin{array}{l}\text { Variabel } \\
\text { independen }\end{array}$ & $\begin{array}{l}\text { Variabel } \\
\text { dependen }\end{array}$ & \\
\hline 23 & $\begin{array}{l}\text { Dorzolamide } \\
\text { hydrochloride }\end{array}$ & Ocular Insert & $\begin{array}{l}\text { Factorial } \\
\text { design }\end{array}$ & $\begin{array}{l}\text { Poloxamer } \\
407 \text { dan PG }\end{array}$ & $\begin{array}{l}\text { Persentase } \\
\text { pelepasan } \\
\text { obat } \\
\text { kumulatif, } \\
\text { ketebalan } \\
\text { dan daya } \\
\text { tahan lipatan }\end{array}$ & (49) \\
\hline 24 & Olopatadine $\mathrm{HCl}$ & Ocular Insert & $\begin{array}{l}\text { Response } \\
\text { Surface } \\
\text { Methodology } \\
\text { (Box- } \\
\text { Bhenken } \\
\text { Design) }\end{array}$ & $\begin{array}{l}\text { Gellan gum, } \\
\text { karbopol } \\
934 \mathrm{P} \text { dan } \\
\text { benzodode } \\
\text { cenium } \\
\text { bromide. }\end{array}$ & $\begin{array}{l}\text { Viskositas } \\
\text { maksimum, } \\
\text { kekuatan } \\
\text { mukoadhesif, } \\
\text { koefisien } \\
\text { permeabilitas } \\
\text { dan } \\
\text { pelepasan } \\
\text { obat }\end{array}$ & $(50)$ \\
\hline 25 & Terconazole & Ocular Insert & $\begin{array}{l}\text { Factorial } \\
\text { design }\end{array}$ & $\begin{array}{l}\text { Cremophor } \\
\text { EL, } \\
\text { Cremophor } \\
\text { RH } 40\end{array}$ & $\begin{array}{l}\text { EE, ukuran } \\
\text { partikel, PDI, } \\
\text { dan ZP. }\end{array}$ & (51) \\
\hline 26 & Fluconazole & Ocular Insert & $\begin{array}{l}\text { Box-Behnken } \\
\text { Design }\end{array}$ & $\begin{array}{l}\text { Chitosan, } \\
\text { NaTPP }\end{array}$ & $\begin{array}{l}\text { EE, dan } \\
\text { diameter } \\
\text { partikel rata- } \\
\text { rata }\end{array}$ & (52) \\
\hline 27 & $\begin{array}{l}\text { Clonidine } \\
\text { hydrochloride }\end{array}$ & Ocular Insert & $\begin{array}{l}\text { Factorial } \\
\text { design }\end{array}$ & $\begin{array}{l}\text { Clonidine } \\
\text { Hydrochlori } \\
\text { de gel, } \\
\text { Poloxamer } \\
407 \text { dan } \\
\text { HPMC } \\
\text { K15M }\end{array}$ & $\begin{array}{l}\text { Suhu } \\
\text { gelasiasi, } \\
\text { kandungan } \\
\text { obat, } \\
\text { kekuatan } \\
\text { bioadhesif, } \\
\text { viskositas. }\end{array}$ & (53) \\
\hline 28 & $\begin{array}{l}\text { Garcinia } \\
\text { Mangostana L. }\end{array}$ & $\begin{array}{l}\text { Self- } \\
\text { nanoemulsifyi } \\
\text { ng Drug } \\
\text { Delivery } \\
\text { System } \\
\text { (SNEDDs) }\end{array}$ & $\begin{array}{l}\text { Simplex } \\
\text { Lattice } \\
\text { Design }\end{array}$ & $\begin{array}{l}\text { Virgin } \\
\text { coconut oil } \\
\text { (VCO), } \\
\text { Tween 80, } \\
\text { PEG } 400\end{array}$ & $\begin{array}{l}\text { Transmisi } \\
\text { dan } \mathrm{pH}\end{array}$ & (54) \\
\hline 29 & $\begin{array}{l}\text { Anti- } \\
\text { inflammatory } \\
\text { Agent } \\
\text { Pentagamavuno } \\
\text { n-0 }\end{array}$ & $\begin{array}{l}\text { Self- } \\
\text { nanoemulsifyi } \\
\text { ng Drug } \\
\text { Delivery } \\
\text { System } \\
\text { (SNEDDs) }\end{array}$ & $\begin{array}{l}\text { Simplex } \\
\text { Lattice } \\
\text { Design }\end{array}$ & $\begin{array}{l}\text { Asam oleat, } \\
\text { Tween 20, } \\
\text { labrasol, } \\
\text { dan PEG } \\
400\end{array}$ & $\begin{array}{l}\text { Ukuran } \\
\text { globul, } \\
\text { konsentrasi } \\
\text { PGV-0 dan } \\
\text { kelarutan } \\
\text { PGV-0 }\end{array}$ & (55) \\
\hline
\end{tabular}


Table 2. Drug Delivery System yang Dioptimasi dengan Design-Expert (lanjutan)

\begin{tabular}{|c|c|c|c|c|c|c|}
\hline \multirow[b]{2}{*}{ No } & \multirow[b]{2}{*}{ Zat aktif } & \multirow[b]{2}{*}{ Sediaan } & \multirow[b]{2}{*}{ Metode } & \multicolumn{2}{|c|}{ Variabel optimasi } & \multirow[b]{2}{*}{ Pustaka } \\
\hline & & & & $\begin{array}{l}\text { Variabel } \\
\text { independen }\end{array}$ & $\begin{array}{l}\text { Variabel } \\
\text { dependen }\end{array}$ & \\
\hline 30 & Polypeptide-k & $\begin{array}{l}\text { Self- } \\
\text { nanoemulsifying } \\
\text { Drug Delivery } \\
\text { System } \\
\text { (SNEDDs) }\end{array}$ & $\begin{array}{l}\text { Response } \\
\text { Surface } \\
\text { Methodology } \\
\text { (Box- } \\
\text { Bhenken } \\
\text { Design) }\end{array}$ & $\begin{array}{l}\text { Oleoyl } \\
\text { polyoxyl-6 } \\
\text { glycerides, } \\
\text { Tween 80, } \\
\text { dan } \\
\text { diethylene } \\
\text { glycol } \\
\text { monoethyl } \\
\text { ether }\end{array}$ & $\begin{array}{l}\text { Ukuran } \\
\text { globul, PDI, } \\
\% \text { pemuatan } \\
\text { obat dan ZP }\end{array}$ & (56) \\
\hline 31 & $\begin{array}{l}\text { Bioflavonoid } \\
\text { hesperetin }\end{array}$ & $\begin{array}{l}\text { Self- } \\
\text { nanoemulsifying } \\
\text { Drug Delivery } \\
\text { System } \\
\text { (SNEDDs) }\end{array}$ & $\begin{array}{l}\text { Central } \\
\text { composite } \\
\text { Design }\end{array}$ & $\begin{array}{l}\text { Linseed oil, } \\
\text { Tween-80, } \\
\text { dan Carbitol }\end{array}$ & $\begin{array}{l}\text { Ukuran globul } \\
\text { dan } \% \\
\text { efisiensi } \\
\text { enkapsulasi }\end{array}$ & (57) \\
\hline 32 & Gemfibrozil & $\begin{array}{l}\text { Self- } \\
\text { nanoemulsifying } \\
\text { Drug Delivery } \\
\text { System } \\
\text { (SNEDDs) }\end{array}$ & $\begin{array}{l}\text { Response } \\
\text { Surface } \\
\text { Methodology } \\
\text { (Box- } \\
\text { Bhenken } \\
\text { Design) }\end{array}$ & $\begin{array}{l}\text { Cremophor, } \\
\text { Capmul } \\
\text { MCM-C8 } \\
\text { dan minyak } \\
\text { atsiri lemon: } \\
\text { Permata (1: } \\
\text { 1) }\end{array}$ & $\begin{array}{l}\text { Karakterisasi } \\
\text { visual, } \\
\text { kekeruhan, } \\
\text { ukuran } \\
\text { tetesan rata- } \\
\text { rata, dan PDI }\end{array}$ & (58) \\
\hline 33 & Atazanavir & $\begin{array}{l}\text { Self- } \\
\text { nanoemulsifying } \\
\text { Drug Delivery } \\
\text { System } \\
\text { (SNEDDs) }\end{array}$ & $\begin{array}{l}\text { Central } \\
\text { composite } \\
\text { design }\end{array}$ & $\begin{array}{l}\text { Jumlah lipid } \\
\text { dan } \\
\text { surfaktan. }\end{array}$ & $\begin{array}{l}\text { Ukuran globul } \\
\text { dan } \quad \% \\
\text { efisiensi } \\
\text { disolusi }\end{array}$ & (59) \\
\hline 34 & Flurbiprofen & $\begin{array}{l}\text { Self- } \\
\text { nanoemulsifying } \\
\text { Drug Delivery } \\
\text { System } \\
\text { (SNEDDs) }\end{array}$ & $\begin{array}{l}\text { Box- } \\
\text { Behnken } \\
\text { Design }\end{array}$ & $\begin{array}{l}\text { Capryol } \\
\text { PGMC, } \\
\text { Tween 20, } \\
\text { dan } \\
\text { Transcutol } \\
\text { HP. }\end{array}$ & $\begin{array}{l}\text { Ukuran } \\
\text { tetesan, } \\
\text { kelarutan } \\
\text { kesetimbanga } \\
\mathrm{n} \text {, dan } \\
\text { persentase } \\
\text { kumulatif } \\
\text { pelepasan } \\
\text { obat }\end{array}$ & (60) \\
\hline 35 & Embelin & $\begin{array}{l}\text { Self- } \\
\text { nanoemulsifying } \\
\text { Drug Delivery } \\
\text { System } \\
\text { (SNEDDs) }\end{array}$ & $\begin{array}{l}\text { Box- } \\
\text { Behnken } \\
\text { design }\end{array}$ & $\begin{array}{l}\text { Capryol 90, } \\
\text { Acrysol EL } \\
135 \text { dan } \\
\text { PEG } 400\end{array}$ & $\begin{array}{l}\text { Waktu } \\
\text { pengemulsi, } \\
\text { ukuran globul } \\
\text { dan } \\
\text { persentase } \\
\text { pelepasan } \\
\text { obat }\end{array}$ & (61) \\
\hline
\end{tabular}


Table 2. Drug Delivery System yang Dioptimasi dengan Design-Expert (lanjutan)

\begin{tabular}{|c|c|c|c|c|c|c|}
\hline \multirow[b]{2}{*}{ No } & \multirow[b]{2}{*}{ Zat aktif } & \multirow[b]{2}{*}{ Sediaan } & \multirow[b]{2}{*}{ Metode } & \multicolumn{2}{|c|}{ Variabel optimasi } & \multirow[b]{2}{*}{ Pustaka } \\
\hline & & & & $\begin{array}{l}\text { Variabel } \\
\text { independen }\end{array}$ & $\begin{array}{l}\text { Variabel } \\
\text { dependen }\end{array}$ & \\
\hline 36 & Glipizide & $\begin{array}{l}\text { Self- } \\
\text { nanoemulsifying } \\
\text { Drug Delivery } \\
\text { System } \\
\text { (SNEDDs) }\end{array}$ & $\begin{array}{l}\text { Central } \\
\text { composite } \\
\text { design }\end{array}$ & $\begin{array}{l}\text { Captex 355, } \\
\text { Solutol HS15, } \\
\text { dan Imwitor } \\
988 .\end{array}$ & $\begin{array}{l}\text { Ukuran } \\
\text { tetesan, } \\
\text { kekeruhan, dan } \\
\text { persentase } \\
\text { pelepasan obat }\end{array}$ & (62) \\
\hline 37 & Furosemide & $\begin{array}{l}\text { Self- } \\
\text { nanoemulsifying } \\
\text { Drug Delivery } \\
\text { System } \\
\text { (SNEDDs) }\end{array}$ & $\begin{array}{l}\text { Simplex } \\
\text { Lattice Design }\end{array}$ & $\begin{array}{l}\text { Capryol-90, } \\
\text { polysorbate- } \\
80 \text {, dan PEG- } \\
400\end{array}$ & $\begin{array}{l}\text { Waktu } \\
\text { emulsifikasi, } \\
\text { kandungan } \\
\text { obat dan } \\
\text { viskositas }\end{array}$ & (63) \\
\hline
\end{tabular}

Artikel penelitian drug delivery system lebih banyak didapatkan dibandingkan dengan formulasi obat konvensial. Hal ini menunjukan trend penelitian pengembangan obat baru lebih banyak ke arah pembuatan drug delivery system. Tujuan pengembangan sediaan ini tidak lain untuk meningkatkan efektivitas dan keamanan obat dengan mengontrol laju, waktu, dan tempat lepas obat di dalam tubuh. ${ }^{23}$ Dalam Tabel 2 terdapat sediaan Transdermal Delivery (TDDs), Gel In Situ, Ocular Insert, dan Selfnanoemulsifying Drug Delivery System (SNEDDs).

Transdermal Delivery (TDDs) merupakan rute sedian dan bentuk sediaan pada umumnya adalah patch. Dalam optimasi sediaan rute transdermal/patch yang menjadi poin penting dalam optimasinya adalah komposisi dari polimer dalam sistem matriks. Polimer dalam matriks tersebut berfungsi untuk mengontrol pelepasan zat aktif. Selain optimasi untuk mendapatkan komposisi polimer yang tepat, dalam artikel Taghizadeh et al. ${ }^{28}$ dilakukan peneletian berupa pemilihan enhancer yang tepat untuk ditambahkan ke dalam formula. Enhancer berfungsi untuk meningkatkan penetrasi obat ke dalam kulit.

Gel In Situ merupakan pengenbangan dari sediaan cair untuk mendapatkan waktu kontak yang lebih lama pada saat diaplikasikan. Bentuk sediaan cair memudahkan saat penggunaan dan akan berubah menjadi gel saat terjadi kontak. Perubahan dari bentuk cair ke bentuk gel dipengaruhi oleh perubahan suhu dan $\mathrm{pH}$ cairan saat kontak dengan bagian tubuh. Penelitian terbaru mengenai formulasi gel in situ dalam artikel Hosny et al, ${ }^{25}$ digunakan untuk pengobatan kanker, pada umunya gel in situ digunakan untuk rute ocular insert. Ocular insert merupakan rute pemberian obat. Perbedaan rute ocular insert dengan rute pemberian lain adalah ocular insert memiliki persyaratan berupa sediaan jadi harus dalam keadaan steril. Contoh sediaan ocular insert selain gel in situ yaitu Soluble Ocular Drug Insert (SODI). Sediaan ini berbentuk oval dan akan berubah menjadi cairan setelah 60 menit pemakaian ${ }^{49}$. 
Self-nanoemulsifying Drug Delivery System (SNEDDs) memiliki cara kerja yang mirip dengan gel in situ, yaitu sediaan akan berubah ketika terjadi kontak, Pada SNEDDs sedian akan berubah menjadi emulsi ketika terjadi kontak dengan asam lambung. Basis sediaan ini adalah minyak, maka dari itu cocok untuk zat aktif yang memiliki kelarutan yang buruk dalam air, contohnya adalah Garcinia Mangostana L. ${ }^{54}$

Komposisi antara surfaktan dengan minyak sangat mempengaruhi karakter dari sediaan tersebut dan hasilnya bisa dilihat dari nilai pada variabel dependen. Dari 10 artikel penelitian tentang SNEDDs, yang menjadi variabel independen adalah minyak dan surfaktan, beberapa dengan tambahan ko-surfaktan, yang membedakan variabel independen 10 artikel tersebut adalah jenis dari minyak dan surfaktan.

\section{Persentase prediction error}

Persentase prediction error merupakan nilai untuk mengukur kesalahan prediksi suatu metode analisis. Dalam review ini tidak semua jurnal mencantumkan nilai prediction error. Nilai prediction error yang dapat diterima adalah $<4 \%$. Seperti dalam penelitian Choudhury et al., ${ }^{13}$ nilai prediction error variabel dependen berada di rentang 2-3,5\% yang artinya masih memenuhi syarat bahwa metode tersebut adalah metode yang tepat untuk melakukan analisa terhadap penelitian yang dilakukan.

\section{Kesimpulan}

Dapat disimpulkan bahwa Design-Expert software bermanfaat dalam formulasi untuk mempermudah formulator menentukan formula optimal. Software dapat digunakan untuk mengevaluasi pengaruh variabel formulasi masing-masing sediaan dengan metode yang berbeda-beda. Design of experiment menggunakan Design-Expert memiliki kelebihan dan kekurangan. Kelebihan DOE dengan Design-Expert adalah dapat mengurangi waktu pengembangan formulasi dan memiliki tingkat keberhasilan yang tinggi dibuktikan dengan dengan derajat desirability dan persentase prediction error. Kekurangan DOE dengan Design-Expert adalah ketergantungan pada software sebagai alat optimasi yang menghasilkan nilai prediction error kurang dari $4 \%$.

\section{Daftar Pustaka}

1. Singh BS, Kapil R, Ahuja N. Systematic optimisation of drug delivery systems: an insight. Pharm Rev. 2008;7:146-186.

2. Ramadhani RA, Riyadi DHS, Triwibowo B, Kusumaningtyas RD. Review Pemanfaatan Design Expert untuk Optimasi Komposisi Campuran Minyak Nabati sebagai Bahan Baku Sintesis Biodiesel. J Tek Kim Dan Lingkung. 2017 Oct $11 ; 1(1): 11$.

3. Carriere J, Vaughn N, Kraber J, Sobczyk P, Bronikowski P, Mazur JM, et al. DesignExpert. 1300 Godward Street Northeast, Suite 6400 Minneapolis, MN 55413: Statease, Inc.; 2019.

4. Bolton S, Bon C. Pharmaceutical statistics: practical and clinical applications. 4th ed., rev.expanded. New York: M. Dekker; 2004. 755 p. (Drugs and the pharmaceutical sciences). 
5. Montgomery DC. Design and Analysis of Experiments. 9th Edition. 2017.

6. Purwanti EP, Pilarian F. S - 11 OPTIMASI PARAMETER PROSES PEMOTONGAN STAINLESS STEEL SUS 304 UNTUK KEKASARAN PERMUKAAN DENGAN METODE RESPONSE SURFACE. 2013;16.

7. Perincek O, Colak M. Use of Experimental Box-Behnken Design for the Estimation of Interactions Between Harmonic Currents Produced by Single Phase Loads. Int J Eng Res Appl. 2013;3(2):8.

8. Damayanti D, Sari IP, Sulaiman TNS, Bestari AN, Setiawan IM. The Formulation of Pacing (Costus speciosus) Extract Tablet by Using Avicel®Ph 200 As Filler-Binder and Amylum As Disintegration Agent. Indones J Pharm. 2018 Jan 2;29(1):29.

9. Murrukmihadi. In Optimasi Formula Sediaan Sirup Mukolitik Vitro Fraksi Terstandar Bunga Kembang Sepatu (Hibiscus rosa-sinensis L.). Dr Diss. 2012;

10. Sainah S. Optimasi Formula Suspensi Siprofloksasin dengan Kombinasi Pulvis Gummi Arabici (Pga) dan Carbopol 934 Menggunakan Metode Desain Faktorial [PhD Thesis]. Tanjungpura University; 2013.

11. Qisti BWK, Nurahmanto D, Rosyidi VA. Optimasi Propilen Glikol dan Etanol sebagai Peningkat Penetrasi Ibuprofen dalam Sediaan Gel dengan Metode Simplex Lattice Design. 2018;6(1):7.

12. Elcistia R, Zulkarnain AK. Optimasi Formula Sediaan Krim o/w Kombinasi Oksibenzon dan Titanium Dioksida Serta Uji Aktivitas Tabir Suryanya Secara In Vivo. Maj Farm. 2019 Jan 14;14(2):63.

13. Choudhury P, Deb P, Dash S. FORMULATION AND STATISTICAL OPTIMIZATION OF BILAYER SUBLINGUAL TABLETS OF LEVOCETIRIZINE HYDROCHLORIDE AND AMBROXOL HYDROCHLORIDE. Asian J Pharm Clin Res. 2016 Sep 1;9(5):228.

14. Usman S, Ejaz RR, Safdar KA. Formulation development and optimization of orally disintegrating tablets of montelukast sodium by Design- Expert. Trop J Pharm Res. 2018 Oct 3;17(9):1701.

15. Khadabadi DSS, Chishti NH, Khan FM, Tadvee AA. FORMULATION AND EVALUATION OF PRESS COATED TABLET OF KETOPROFEN - A CHRONOTHERAPEUTIC APPROACH. 2013;5:8.

16. Bushra R, Shoaib MH, Ali H, Zafar F, Naeem Ml, Aslam N, et al. Formulation Design and Optimization of Aceclofenac Tablets $(100 \mathrm{mg})$ Using Central Composite Design with Response Surface Methodology. 2014;11.

17. Na Y-G, Jeon S-H, Byeon J-J, Kim M-K, Lee H-K, Cho C-W. Application of statistical design on the early development of sustained-release tablet containing ivy leaf extract. J Drug Deliv Sci Technol. 2019 Dec;54:101319.

18. Esim O, Savaser A, Ozkan CK, Bayrak Z, Tas C, Ozkan Y. Effect of polymer type on characteristics of buccal tablets using factorial design. Saudi Pharm J. 2018 Jan;26(1):53-63.

19. Naveen NR, Gopinath C, Rao DS. Design expert supported mathematical optimization of repaglinide gastroretentive floating tablets: In vitro and in vivo evaluation. Future J Pharm Sci. 2017 Dec;3(2):140-7.

20. Reddy Y, Chetty C, Kumar K, Dachinamoorthi D. Formulation and Optimization of Extended Release Matrix Tablets of Losartan Potassium Using Response Surface Methodology (RSM). J Pharm Res Int. 2017 Jan 10;19(5):1-12. 
21. Sarkhejiya NA, Khachar KK, Patel VP. Formulation Development and Evaluation of Sublingual Tablet of Risperidone. 2013;7.

22. Widiastuti L. Formulasi Granul Kombinasi Ekstrak Terpurifikasi Herba Pegagan (Centella asiatica (L.) Urban) dan Herba Sambiloto (Andrographis paniculata (Burm. f.) Nees) [PhD Thesis]. Universitas Gadjah Mada; 2013.

23. Putra IMWA, Mustika IG. Potensi Zat Aktif Antikanker Solasodin Terenkapusulasi Pada Zeolit Klinoptilolit Sebagai Sistem Pengantar Obat (Drug Delivery System). Cakra Kim Indones E-J Appl Chem. 2016 Oktober;4(2):1-10.

24. Mehdizadeh A, Ghahremani MH, Rouini MR, Toliyat T. Effects of pressure sensitive adhesives and chemical permeation enhancers on the permeability of fentanyl through excised rat skin. Acta Pharm. 2006;11

25. Hosny KM, Rizg WY, Khallaf RA. Preparation and Optimization of In Situ Gel Loaded with Rosuvastatin-Ellagic Acid Nanotransfersomes to Enhance the Anti-Proliferative Activity. Pharmaceutics. 2020 Mar 13;12(3):263.

26. Kumar S, Nagori BP, Issarani R, Ahuja M. Ocular Insert: Dosage Form for Sustain Opthalmic Drug Delivery. 2012;1:13.

27. Sun M, Han J, Guo X, Li Z, Yang J, Zhang Y, et al. Design, preparation and in vitro evaluation of paclitaxel-loaded self-nanoemulsifying drug delivery system. Asian $\mathrm{J}$ Pharm Sci. 2011;8.

28. Taghizadeh SM, Moghimi-Ardakani A, Mohamadnia F. A statistical experimental design approach to evaluate the influence of various penetration enhancers on transdermal drug delivery of buprenorphine. J Adv Res. 2015 Mar;6(2):155-62.

29. Ahmed OAA, Badr-Eldin SM. Development of an optimized avanafil-loaded invasomal transdermal film: Ex vivo skin permeation and in vivo evaluation. Int $\mathrm{J}$ Pharm. 2019 Oct;570:118657.

30. Malakar J, Sen SO, Nayak AK, Sen KK. Formulation, optimization and evaluation of transferosomal gel for transdermal insulin delivery. Saudi Pharm J. 2012 Oct;20(4):355-63.

31. Chauhan MK, Sharma PK. Optimization and characterization of rivastigmine nanolipid carrier loaded transdermal patches for the treatment of dementia. Chem Phys Lipids. 2019 Nov;224:104794.

32. Ma H, Guo D, Fan Y, Wang J, Cheng J, Zhang X. Paeonol-Loaded Ethosomes as Transdermal Delivery Carriers: Design, Preparation and Evaluation. Molecules. 2018 Jul 17;23(7):1756.

33. Michaelis $M$, Leopold CS. Mixture design approach for early stage formulation development of a transdermal delivery system. Drug Dev Ind Pharm. 2015 Sep 2;41(9):1532-40.

34. Akhlaq M, Arshad MS, Mudassir AM, Hussain A, Kucuk I, Haj-Ahmad R, et al. Formulation and evaluation of anti-rheumatic dexibuprofen transdermal patches: a quality-by-design approach. J Drug Target. 2016 Aug 8;24(7):603-12.

35. Duangjit S, Mehr LM, Kumpugdee-Vollrath M, Ngawhirunpat T. Role of Simplex Lattice Statistical Design in the Formulation and Optimization of Microemulsions for Transdermal Delivery. Biol Pharm Bull. 2014;37(12):1948-57.

36. Nanda DS, Saroha K, Sharma B. Formulation, Evaluation And Optimization Of Transdermal Gel Of Ketorolac Tromethamine Using Face Centered Central Composite Design. 2014;6(4):7. 
36. Kamran Mohd, Ahad A, Aqil Mohd, Imam SS, Sultana Y, Ali A. Design, formulation and optimization of novel soft nano-carriers for transdermal olmesartan medoxomil delivery: In vitro characterization and in vivo pharmacokinetic assessment. Int $\mathrm{J}$ Pharm. 2016 May;505(1-2):147-58.

37. Elmotasem H, Awad GEA. A stepwise optimization strategy to formulate in situ gelling formulations comprising fluconazole-hydroxypropyl-beta-cyclodextrin complex loaded niosomal vesicles and Eudragit nanoparticles for enhanced antifungal activity and prolonged ocular delivery. Asian J Pharm Sci. 2019 Dec;S1818087619307962.

38. Patel S, Koradia H, Parikh R. Design and development of intranasal in situ gelling system of Midazolam hydrochloride using 32 full factorial design. J Drug Deliv Sci Technol. 2015 Dec;30:154-62.

39. Alharbi WS, Hosny KM. Development and optimization of ocular in situ gels loaded with ciprofloxacin cubic liquid crystalline nanoparticles. J Drug Deliv Sci Technol. 2020 Jun;57:101710.

40. Wadetwar RN, Agrawal AR, Kanojiya PS. In situ gel containing Bimatoprost solid lipid nanoparticles for ocular delivery: In-vitro and ex-vivo evaluation. J Drug Deliv Sci Technol. 2020 Apr;56:101575.

41. Shah V, Sharma M, Pandya R, Parikh RK, Bharatiya B, Shukla A, et al. Quality by Design approach for an in situ gelling microemulsion of Lorazepam via intranasal route. Mater Sci Eng C. 2017 Jun;75:1231-41.

42. Das T, Venkatesh MP, Pramod Kumar TM, Koland M. SLN based alendronate in situ gel as an implantable drug delivery system - A full factorial design approach. J Drug Deliv Sci Technol. 2020 Feb;55:101415.

43. Rao M, Agrawal DK, Shirsath C. Thermoreversible mucoadhesive in situ nasal gel for treatment of Parkinson's disease. Drug Dev Ind Pharm. 2017 Jan 2;43(1):14250.

44. Galgatte UC, Kumbhar AB, Chaudhari PD. Development of in situ gel for nasal delivery: design, optimization, in vitro and in vivo evaluation. Drug Deliv. 2014 Feb;21(1):62-73.

45. Shastri D, Prajapati S, Patel L. Thermoreversible mucoadhesive ophthalmic in situ hydrogel: Design and optimization using a combination of polymers. Acta Pharm [Internet]. 2010 Jan 1 [cited 2020 Jun 9];60(3). Available from: https://content.sciendo.com/doi/10.2478/v10007-010-0029-4.

46. Shivakumar HN, Desai BG, Subhash PG, Ashok P, Hulakoti B. Design of ocular inserts of brimonidine tartrate by response surface methodology. J Drug Deliv Sci Technol. 2007;17(6):421-30.

47. Bhattacharjee A, Das PJ, Dey S, Nayak AK, Roy PKr, Chakrabarti S, et al. Development and optimization of besifloxacin hydrochloride loaded liposomal gel prepared by thin film hydration method using 32 full factorial design. Colloids Surf Physicochem Eng Asp. 2020 Jan;585:124071.

48. Patil SS, Bade A, Tagalpallewar A. Design, optimization and pharmacodynamic comparison of dorzolamide hydrochloride soluble ocular drug insert prepared by using 32 factorial design. J Drug Deliv Sci Technol. 2018 Aug;46:138-47.

49. Ranch KM, Maulvi FA, Naik MJ, Koli AR, Parikh RK, Shah DO. Optimization of a novel in situ gel for sustained ocular drug delivery using Box-Behnken design: In vitro, ex vivo, in vivo and human studies. Int J Pharm. 2019 Jan;554:264-75. 
50. Abdelbary AA, Abd-Elsalam WH, Al-mahallawi AM. Fabrication of novel ultradeformable bilosomes for enhanced ocular delivery of terconazole: In vitro characterization, ex vivo permeation and in vivo safety assessment. Int $\mathrm{J}$ Pharm. 2016 Nov;513(1-2):688-96.

51. Chopra AK, Marwaha RK, Deepak K. Box-Behnken Designed Fluconazole Loaded Chitosan Nanoparticles for Ocular Delivery. J Pharm Drug Deliv Res [Internet]. 2014 [cited 2020 Jun 9];03(01). Available from: http://scitechnol.com/boxbehnkendesigned-fluconazole-loaded-chitosan-nanoparticles-for-ocular-delivery-

9tum.php?article_id=2488

52. Avinash K, Ajay S. FORMULATION AND EVALUATION OF THERMOREVERSIBLE IN SITU OCULAR GEL OF CLONIDINE HYDROCHLORIDE FOR GLAUCOMA. 2015;6:13.

53. Pratiwi L, Fudholi A, Martien R, Pramono S. Self-nanoemulsifying Drug Delivery System (Snedds) for Topical Delivery of Mangosteen Peels (Garcinia Mangostana L.,): Formulation Design and In vitro Studies. J Young Pharm. 2017 Jul 1;9(3):341-6.

54. Astuti IY, Marchaban M, Martien R, Nugroho AE. Design and Optimization of Self Nano-Emulsifying Drug Delivery System Containing a New Anti-inflamatory Agent Pentagamavunon-0. Indones J Chem. 2017 Nov 30;17(3):365-75.

55. Garg V, Kaur P, Singh SK, Kumar B, Bawa P, Gulati M, et al. Solid selfnanoemulsifying drug delivery systems for oral delivery of polypeptide-k: Formulation, optimization, in-vitro and in-vivo antidiabetic evaluation. Eur $\mathrm{J}$ Pharm Sci. 2017 Nov;109:297-315.

56. Arya A, Ahmad H, Tulsankar S, Agrawal S, Mittapelly N, Boda R, et al. Bioflavonoid hesperetin overcome bicalutamide induced toxicity by co-delivery in novel SNEDDS formulations: Optimization, in vivo evaluation and uptake mechanism. Mater Sci Eng C. 2017 Feb;71:954-64.

57. Villar AMS, Naveros BC, Campmany ACC, Trenchs MA, Rocabert CB, Bellowa LH. Design and optimization of self-nanoemulsifying drug delivery systems (SNEDDS) for enhanced dissolution of gemfibrozil. Int J Pharm. 2012 Jul;431(1-2):161-75.

58. Singh G, Pai RS. Optimized self-nanoemulsifying drug delivery system of atazanavir with enhanced oral bioavailability: in vitro/in vivo characterization. Expert Opin Drug Deliv. 2014 Jul;11(7):1023-32.

59. Marasini N, Yan YD, Poudel BK, Choi H, Yong CS, Kim JO. Development and Optimization of Self-Nanoemulsifying Drug Delivery System with Enhanced Bioavailability by Box-Behnken Design and Desirability Function. J Pharm Sci. 2012 Dec;101(12):4584-96.

60. Parmar K, Patel J, Sheth N. Self nano-emulsifying drug delivery system for Embelin: Design, characterization and in-vitro studies. Asian J Pharm Sci. 2015 Oct;10(5):396-404.

61. Dash RN, Mohammed H, Humaira T, Ramesh D. Design, optimization and evaluation of glipizide solid self-nanoemulsifying drug delivery for enhanced solubility and dissolution. Saudi Pharm J. 2015 Oct;23(5):528-40. 
62. Fithri NA, Mardiyanto M, Novita RP, Andrean V. Furosemide self nano emulsifying drug delivery system (SNEDDS) formulation comprising of capryol-90, polysorbate80, and peg-400 with simplex-lattice-design. Sci Technol Indones. 2017 Oct 3;2(4):85-8. 